\title{
The Changing Landscape Of The Indian Banking Industry: An Empirical Study
}

Sivakumar Venkataramany, Ashland University, USA

Balbir B. Bhasin, University of Arkansas, USA

\begin{abstract}
While global financial deregulation has led to liberalization of financial services and thus to modernization of commercial banking, industrialized economies are facing a financial meltdown. The health of the major global banking industry is under severe stress, but India continues to be strong. Despite cost prohibitive efforts in the introduction of a range of new products and services, banks in India are striving to emerge from an era of development banking into consumer-oriented supermarkets. This paper studies the Indian banking industry with regard to its readiness to move on to the next generation.
\end{abstract}

Keywords: India; Banking Industry; Financial Services; Risk Management

\section{INTRODUCTION}

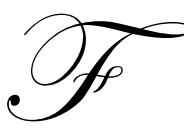

ollowing global financial deregulation, developing economies have engaged in rapidly increasing the efficiency of various industries. Any attempt to revamp their financial services industry will lead to a major integration of services and the introduction of a range of new products. This will also require a complete overhaul of technology, starting from automated teller machines, internet banking, point-of-sale transaction processing, credit card operations, efficient telecommunication service for data transmission, and assisting investors with a whole plethora of alternative investment vehicles. Modernization of the financial services industry will be fruitful only when it is accompanied by adequate risk management. Risk management in the banking industry has thus become a global phenomenon. This is an area where the Bank for International Settlements (BIS) is working with various central banks to ensure the presence of a uniform and harmonized approach.

\section{LITERATURE REVIEW}

Banks are exposed to a variety of risks, namely, credit risk, liquidity risk, exchange risk, operational risk, transparency risk, reputation risk, interest rate risk, technology risk etc. The BIS recommends the need for an adequate amount of capital to help banks temporarily absorb any unexpected fluctuation and/or losses. Central banks of countries follow the guidelines of the BIS and introduce befitting policies and procedures in the context of their markets. As more products and services are introduced, the policies must be flexible enough to accommodate the requisite changes. The successful negotiation and implementation of Basel II Accord will lead to a sharp focus on the risk measurement and risk management at the institutional level [Arora, Garg and Ranjan, 2007]. Indian banking industry in general uses a credit committee for decision making and the managements of most banks perform industry studies make periodic credit calls, undertake regular plant visits, and conduct annual review of accounts for credit risk management. Irrespective of the bank size and sector, the credit risk framework follows guidelines provided by the country's central bank, namely, the Reserve Bank of India [Bodla and Verma, 2009]. The information contained in bank financial statements may be used to assess the risk management capabilities of banks and then ascertain the sensitivity of bank stocks to risk management [Sensarma and Jayadev, 2009].

The impact of credit rating on capital adequacy ratios of the state-owned banking industry needs short and long term perspectives [Nachane and Ghoshal, 2004]. The financial services industry is undergoing drastic changes through convergence between sectors and integration of products thereby requiring different type of regulation 
[Singhal and Vij, 2006]. If Indian banking industry follows the global trend of consolidation, critical issues must be assessed regarding two important stakeholders, that is, shareholders and managers [Jayadev and Sensarma, 2007]. Operational risk is the risk of loss resulting from failure to administer efficient internal control processes within a bank. The regulators ensure that the management of the banking system is following the guidelines in this regard. Banks in India are directed to follow Basic Indicator Approach (BIA) for operational risk capital charge calculation [Bodla and Verma, 2008]. A survey conducted on select banks in India indicates insufficient internal data and difficulties in collection of external loss data. Hence it is imperative that banks devote time and resources to implement the advanced approach under Basel II [Janakiraman, 2008].

A study of the technical efficiency scores across a set of private and public sector banks reveals that the private sector banks have higher technical efficiency scores than their public sector counterparts [Sinha, 2008]. Management of interest rate risk in the banking system has become significant because there is the possibility of significant basis risk in addition to re-pricing risk [Saha, Subramanian, Basu, and Mishra, 2009]. Agricultural and other priority sector loan exposures may be typically managed on a portfolio basis. This will enable banks to diversify the risk and optimize the profit in the business besides strengthening a bank's relationship with its clients. Transparency in loan decision making process will continue to expand to reach benefits of corporate governance [Bandyopadhyay, 2008]. Finance companies that operate in the unorganized segments must also be required to become Basel II compliant but with a higher capital adequacy ratio [Ghoshal, 2008]. A modified and improved approach for the development of risk assessment must include an audit plan and an outline of the acceptable levels of risk for identifying risk mitigation measures [Khanna, 2008].

\section{The Indian Banking Industry - A Historical Perspective}

Following the nationalization of twenty major commercial banks starting in 1969, the government followed policies of financial repression for nearly two decades. The public sector commercial banks experienced rapid expansion of network of branches, including rural areas. They did not have any competition in their deposit mobilization efforts and using the depositors' funds in the disbursement of loans. While employment in the banking industry increased exponentially, the highly educated and motivated bank employees and managers had no discretion or autonomy in their decision making. Interest rates were administered by the Reserve Bank of India for deposits and loans. Direction of credit was also determined by the central bank and the government.

The cost burden continued to increase with high salaries for employees and high interest rates for deposits and that for loans was artificially kept low to suggest development banking. Depositors had no viable and dependable alternative investment vehicles. Commercial credit was at a high and unaffordable cost. Thus, the operating efficiency of public sector commercial banks rapidly declined due to the aforesaid reasons. The banking industry went through a transformation in the last decade due to the financial liberalization efforts of the government. Entry barriers were removed permitting fresh private banks to operate thereby making the industry competitive. Rate deregulation also was introduced in stages. The implementation of Basel I capital adequacy norms led to banks finding avenues for a fresh infusion of capital. Cost cutting was inevitable leading to generating fee based income sources. The public sector commercial banks have yet to fully expand their off-balance sheet activities compared to their traditional fund-based activities [Sinha 2008]. Figure 1 shows that the banking industry in India still commands a major market share in the financial savings of the household sector. While a range of new financial products has become available, the household sector is mostly risk averse and also not so financially literate to assess the relationship between risk and reward. Thus, the imperative for the banking industry is to scan the financial market on behalf of its clients for a superior rate of return for a fee.

\section{EMPIRICAL STUDY OF THE BANKING INDUSTRY IN INDIA}

Any attempt to study the efficiency of individual banks and the effectiveness of the banking system will have to start with the segments within the industry. Our data comprises sector wise standing of the banking industry from 1979 to 2009 divided into State Bank of India \& associates, nationalized banks (also known as public sector banks), regional rural banks, private banks, and foreign banks. The regional rural banks were constituted for a specific purpose of "development of agriculture, trade, commerce, industry and other productive activities in the rural areas, credit and other facilities, particularly to the small and marginal farmers, agricultural labourers, artisans 
and small entrepreneurs"1. We included twenty-nine ratios of the industry as a measure of the industry's readiness to display efficiency, profitability and also proceed with Basel II implementations. The ratios that we studied are: Cash to deposit, Credit to deposit, Investment to deposit, Credit and investment to deposit, Deposits to total liabilities, Term deposits to total deposits, Priority sector credit to total credit, Term loan to total credit, Secured advances to total advances, Investments in non-approved securities to total investments, Interest income to total assets, Net interest margin to total assets, Non-interest income to total assets, Intermediation cost to total assets, Wages to intermediation cost, Wages to total expense, Wages to total income, Burden to total assets, Burden to interest income, Operating profits to total assets, Return on assets, Return on equity, Cost of deposits, Cost of borrowings, Cost of funds, Return on loans, Return on investments, Return on loans adjusted to cost of funds, and Return on investments adjusted to cost of funds. The correlation matrix for select variables is shown in Table 1. If the industry has sufficient products to invest in, its profitability will be visible in its return on assets (ROA). The same will also suggest the presence of liquidity risk, credit (default) risk, operational risk, and interest rate risk. So, we included key independent variables, namely, cost of deposits, cost of borrowing, cost of funding, return on loans, return on investments, intermediation cost, term deposits, priority sector credit, term liabilities, and total liabilities.

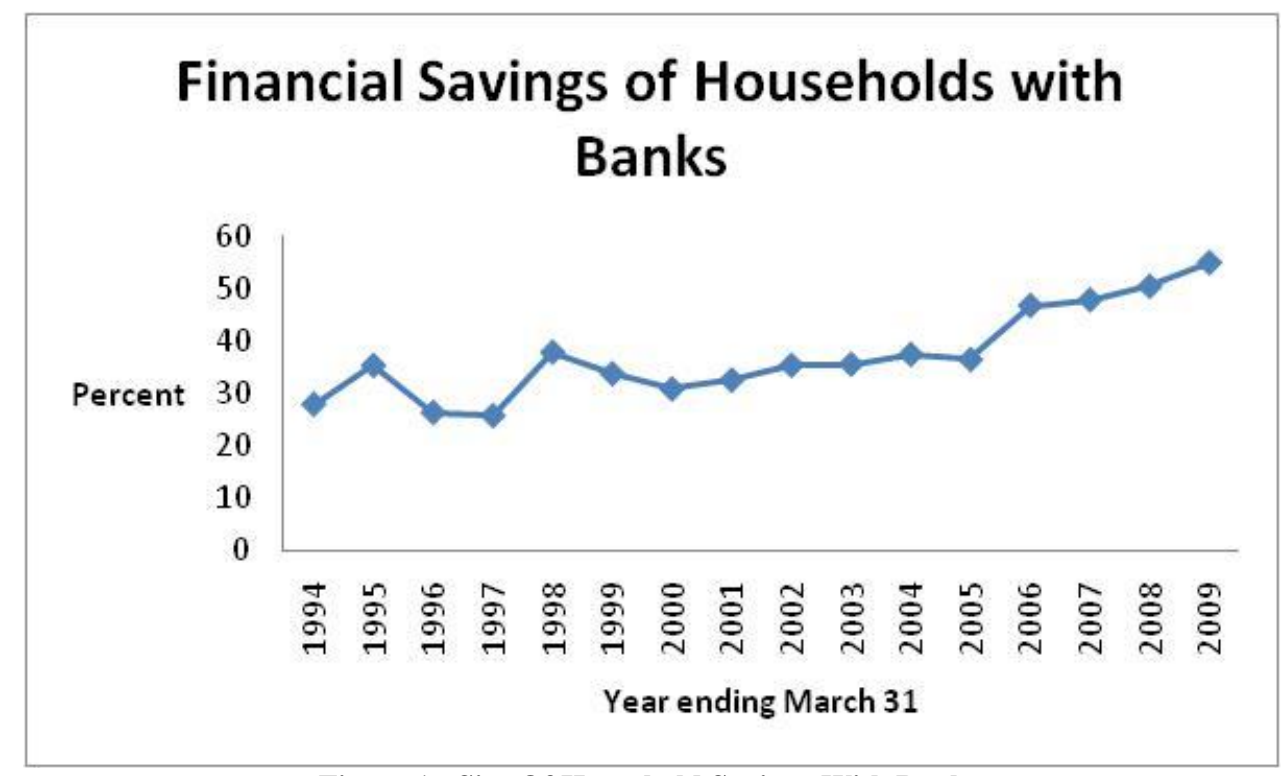

Figure 1: Size Of Household Savings With Banks

\section{Hypothesis 1:}

ROA $=\alpha$ (constant) $+\beta_{1}$ (cost of deposits) $+\beta_{2}$ (cost of borrowing) $+\beta_{3}$ (cost of funding) $+\beta_{4}$ (return on loans adjusted to cost of funds) $+\beta_{5}$ (return on investments) $+\beta_{6}$ (intermediation cost of funds)

\section{Hypothesis 1A:}

ROA $=\alpha$ (constant) $+\beta_{1}$ (cost of deposits) $+\beta_{2}$ (cost of borrowing) $+\beta_{3}$ (cost of funding) $+\beta_{4}$ (return on loans adjusted to cost of funds) $+\beta_{5}$ (return on investments) $+\beta_{6}$ (intermediation cost of funds) $+\beta_{6}$ (Dummy variable for foreign banks)

\footnotetext{
${ }^{1}$ The Regional Rural Banks Act, 1976 (Act No. 21 of 1976), dated 9th February, 1976 
Table 1: Correlation Matrix of Select Ratios of Indian Banking Industry (1979-2009)

\begin{tabular}{|c|c|c|c|c|c|c|c|c|c|c|c|c|c|c|c|c|c|c|c|c|c|c|c|c|}
\hline & TDTDEP & PRADVTL & TRMLTAD & SECTADV & JINTINTA & NIIITA & JONINT & |NTERCST & WAGEIC & WAGETI & |BURDTA & BURINC & BURDENII & TOPPRTA & ROA & ROE & DEPCST & BORCST & FNDCST & ROLOAN & ROI & ROLADJ & ROIADJ & DUMAYY \\
\hline TDTDEP & 1.000 & & & & & & & & & & & & & & & & & & & & & & & \\
\hline PRADVTL & $-.741^{-1}$ & 1.000 & & & & & & & & & & & & & & & & & & & & & & \\
\hline TRIMLTAD & $-.272^{-1}$ & $.503^{-1}$ & 1.000 & & & & & & & & & & & & & & & & & & & & & \\
\hline SECTADV & \begin{tabular}{|c|}
-0.147 \\
\end{tabular} & $334^{-1}$ & -0.192 & 1.000 & & & & & & & & & & & & & & & & & & & & \\
\hline NTINTA & $264^{-}$ & -0.195 & -0.116 & $-.286^{-1}$ & 1.000 & & & & & & & & & & & & & & & & & & & \\
\hline NIITTA & 0.181 & -0.173 & -0.041 & $-.507^{-1}$ & $875^{-1}$ & 1.000 & & & & & & & & & & & & & & & & & & \\
\hline NONINT & $386^{-1}$ & $-.531^{-1}$ & -0.040 & $-.730^{-1}$ & .593 & $.776^{\circ}$ & 1.000 & & & & & & & & & & & & & & & & & \\
\hline INTERCST & -0.017 & 0.054 & 0.076 & $-375^{-1}$ & $.886^{-1}$ & $.820^{\circ}$ & $.545^{\circ}$ & 1.000 & & & & & & & & & & & & & & & & \\
\hline WAGEIC & $-.628^{-1}$ & $655^{-1}$ & -0.011 & $.637^{\prime \prime}$ & - $194^{4}$ & $-327^{7}$ & $-672^{-1}$ & -0.133 & 1.000 & & & & & & & & & & & & & & & \\
\hline WAGETI & $-844^{-1}$ & $803^{-1}$ & 0.203 & $381^{\prime \prime}$ & $-279^{-1}$ & $-.259^{\circ}$ & $-.542^{-1}$ & -0.022 & $857^{\circ}$ & 1.000 & & & & & & & & & & & & & & \\
\hline BURDTA & $-.760^{-1}$ & $838^{-1}$ & $280^{-1}$ & $.411^{-1}$ & $-260^{-1}$ & $.348^{\circ}$ & $-601^{-1}$ & 0.012 & $.796^{-1}$ & $.940^{\circ}$ & 1.000 & & & & & & & & & & & & & \\
\hline BURINC & $-388^{-1}$ & $630^{-1}$ & 0.130 & $.358^{\prime \prime}$ & $.424^{-1}$ & 0.175 & $-.348^{\circ}$ & .597" & $.495^{-1}$ & $.494^{\prime \prime}$ & $.589^{\circ}$ & 1.000 & & & & & & & & & & & & \\
\hline BURDENNII & $-660^{-1}$ & $830^{-1}$ & $278^{-1}$ & $.422^{-1}$ & -0.141 & $.298^{-1}$ & $-633^{-1}$ & 0.125 & $670^{-1}$ & $.802^{-1}$ & $.928^{-1}$ & $.746^{\circ}$ & 1.000 & & & & & & & & & & & \\
\hline OPPRTA & $.412^{-1}$ & $-.538^{-1}$ & -0.116 & $-667^{-1}$ & .503" & $.773^{-1}$ & $.912^{-1}$ & $343^{-1}$ & $-609^{-1}$ & $-.550^{\circ}$ & $-689^{\circ}$ & $-.489^{-1}$ & $-.746^{\circ}$ & 1.000 & & & & & & & & & & \\
\hline ROA & . $194^{4}$ & $-322^{-1}$ & 0.046 & $-.400^{-1}$ & 0.144 & $.429^{\circ}$ & $.595^{\circ}$ & 0.069 & $-.403^{-1}$ & $-377^{7}$ & $-.549^{\circ}$ & $-.493^{-1}$ & $-.618^{\circ}$ & $.696^{\circ}$ & 1.000 & & & & & & & & & \\
\hline ROE & 0.156 & $-291^{-1}$ & -0.017 & $-219^{\circ}$ & 0.174 & $.278^{\circ}$ & $.401^{\circ}$ & 0.148 & $-342^{-1}$ & $-344^{\prime \prime}$ & $-.406^{-1}$ & $-219^{\circ}$ & $-347^{\circ}$ & $.387^{7}$ & $.746^{\circ}$ & 1.000 & & & & & & & & \\
\hline DEPCST & 0.091 & -0.067 & -0.084 & -0.061 & $.884^{-1}$ & $.606^{-1}$ & $255^{\circ}$ & $.814^{-1}$ & 0.149 & -0.024 & 0.026 & $.622^{-2}$ & 0.126 & 0.128 & \begin{tabular}{l|l|}
8 & -0.082 \\
\end{tabular} & -0.032 & 1.000 & & & & & & & \\
\hline BORCST & $362^{-2}$ & $-325^{-1}$ & $-356^{-1}$ & $-327^{\prime \prime}$ & $.714^{-1}$ & $.636^{\circ}$ & .563" & .547- & $-.414^{-1}$ & $-407^{-1}$ & $-.313^{-1}$ & 0.012 & -0.198 & $.557^{\circ}$ & 0.028 & 0.055 & $.497^{-1}$ & 1.000 & & & & & & \\
\hline FNDCST & 0.190 & -0.163 & -0.164 & -0.149 & $.969^{-1}$ & $.753^{-1}$ & $.479^{-1}$ & $821^{-}$ & -0.020 & -0.151 & -0.112 & $.412^{-1}$ & -0.040 & $.419^{\circ}$ & -0.047 & \begin{tabular}{|c|} 
\\
\end{tabular} & $.975^{-1}$ & $.662^{-1}$ & 1.000 & & & & & \\
\hline ROLOAN & 0.133 & -265 & -0.184 & $-332^{-2}$ & $.869^{-1}$ & $.668^{-1}$ & $.409^{-1}$ & $818^{-1}$ & -0.108 & -0.171 & -0.107 & $.479^{-1}$ & 0.023 & $.273^{\circ}$ & 0.015 & \begin{tabular}{|l|l|} 
& 0.070 \\
\end{tabular} & $.894^{-1}$ & $.790^{-}$ & $.930^{-1}$ & 1.000 & & & & \\
\hline ROI & 0.118 & -0.161 & $-211^{-}$ & -0.202 & .933- & $.849^{-1}$ & $519^{-1}$ & $828^{-}$ & -0.029 & -0.113 & -0.170 & $.377^{-1}$ & -0.119 & $.524^{4}$ & 0.133 & 0.069 & $.896^{-1}$ & $.592^{-1}$ & $.913^{-1}$ & $.865^{\circ}$ & 1.000 & & & \\
\hline ROLADJ & 236 & $-331^{-1}$ & -0.179 & $-.469^{-1}$ & $840^{-2}$ & $.865^{\circ}$ & $.760^{\circ}$ & .743- & $-.466^{-1}$ & $-375^{-1}$ & $-368^{-1}$ & 0.022 & $-287^{-1}$ & $.753^{-1}$ & $.225^{\circ}$ & 0.138 & $.605^{-1}$ & $.806^{-1}$ & $.729^{-1}$ & $.930^{-1}$ & $.694^{-1}$ & 1.000 & & \\
\hline ROIADJ & -0.016 & -0.110 & $-216^{\circ}$ & $-.216^{-}$ & .607" & $.731^{1}$ & $.421^{\circ}$ & .594- & -0.033 & -0.026 & -0.201 & $.218^{\circ}$ & $\begin{array}{l}-0.194 \\
\end{array}$ & $.515^{\circ}$ & $.344^{-1}$ & $235^{\circ}$ & $.523^{-1}$ & $.320^{-}$ & $.524^{-1}$ & $.519^{-1}$ & $.825^{-1}$ & $.442^{-1}$ & 1.000 & \\
\hline DUMAYYY & $.213^{-1}$ & $-385^{-1}$ & -0.052 & $-.778^{\prime \prime}$ & $290^{-1}$ & $.507^{\circ}$ & $.724^{-1}$ & $334^{-1}$ & $-.761^{-1}$ & $-.516^{-1}$ & $-.513^{-1}$ & $-320^{-1}$ & $-441^{\circ}$ & $.656^{\circ}$ & $.390^{-1}$ & $315^{-1}$ & -0.062 & $.545^{-1}$ & 0.139 & .1911 & $.220^{\circ}$ & $.544^{-1}$ & .267 & 1.000 \\
\hline
\end{tabular}

Correlation is significant at the 0.05 level (2-tailed.

tr. Correlation is significant at the 0.01 level (2-tailed) 


\section{Hypothesis 2:}

ROA $=\alpha$ (constant) $+\beta_{1}$ (term deposits to total deposits) $+\beta_{2}$ (priority sector credit to total credit) $+\beta_{3}$ (term liabilities to total liabilities) $+\beta_{4}$ (secured credit to total liabilities) $+\beta_{5}$ (net interest margin to total assets) $+\beta_{6}$ (noninterest income to total assets) $+\beta_{7}$ (operating profit to total assets)

\section{Hypothesis 2A:}

ROA $=\alpha$ (constant) $+\beta_{1}$ (term deposits to total deposits) $+\beta_{2}$ (priority sector credit to total credit) $+\beta_{3}$ (term liabilities to total liabilities) $+\beta_{4}$ (secured credit to total liabilities) $+\beta_{5}$ (net interest margin to total assets) $+\beta_{6}$ (operating profit to total assets) $+\beta_{7}$ (Dummy variable for foreign banks)

\section{Hypothesis 3:}

ROA $=\alpha$ (constant) $+\beta_{1}$ (term deposits to total deposits) $+\beta_{2}$ (priority sector credit to total credit) $+\beta_{3}$ (term liabilities to total liabilities) $+\beta_{4}$ (secured credit to total liabilities) $+\beta_{5}$ (net interest margin to total assets) $+\beta_{6}$ (operating profit to total assets)

\section{Hypothesis 3A:}

ROA $=\alpha$ (constant) $+\beta_{1}$ (term deposits to total deposits) $+\beta_{2}$ (priority sector credit to total credit) $+\beta_{3}$ (term liabilities to total liabilities) $+\beta_{4}$ (secured credit to total liabilities) $+\beta_{5}$ (net interest margin to total assets) $+\beta_{6}$ (operating profit to total assets) $+\beta_{7}$ (Dummy variable for foreign banks)

India's foreign direct investment policy for the banking industry was fully liberalized in January 2000 and so we studied the same data using the same hypotheses for the years 2000 to 2009 separately. We also realized the need to examine the return on equity (ROE) as one of the dependant variables using similar hypotheses.

\section{Hypothesis 4:}

$\mathrm{ROE}=\alpha$ (constant) $+\beta_{1}$ (Interest income to total assets) $+\beta_{2}$ (Net interest margin to total assets) $+\beta_{3}$ (Non-interest income to total assets) $+\beta_{4}$ (Intermediation cost to total assets) $+\beta_{5}$ (Wages to total income) $+\beta_{6}$ (intermediation cost of funds)

\section{Hypothesis 4A:}

$\mathrm{ROE}=\alpha$ (constant) $+\beta_{1}$ (Interest income to total assets) $+\beta_{2}$ (Net interest margin to total assets) $+\beta_{3}$ (Non-interest income to total assets) $+\beta_{4}$ (Intermediation cost to total assets) $+\beta_{5}$ (Wages to total income) $+\beta_{6}$ (intermediation cost of funds) $+\beta_{7}$ (Dummy variable for foreign banks)

\section{Hypothesis 5 (2000 to 2009):}

$\mathrm{ROE}=\alpha$ (constant) $+\beta_{1}$ (Interest income to total assets) $+\beta_{2}$ (Net interest margin to total assets) $+\beta_{3}$ (Non-interest income to total assets) $+\beta_{4}$ (Intermediation cost to total assets) $+\beta_{5}$ (Wages to total income) $+\beta_{6}$ (intermediation cost of funds)

\section{Hypothesis 5A (2000 to 2009):}

$\mathrm{ROE}=\alpha$ (constant) $+\beta_{1}$ (Interest income to total assets) $+\beta_{2}$ (Net interest margin to total assets) $+\beta_{3}$ (Non-interest income to total assets) $+\beta_{4}$ (Intermediation cost to total assets) $+\beta_{5}$ (Wages to total income) $+\beta_{6}$ (intermediation cost of funds) $+\beta_{7}$ (Dummy variable for foreign banks)

The public sector banks lacked original equity and so started issuing new equity to the public. The entire State Bank group thrives on government accounts and also acts as an agent of the country's central bank thus, only 
the newly licensed private banks are funded by original equity. A few public sector banks have initiated the process of initial public offerings to infuse fresh and real equity into their financial health. Table 2 shows the number of issues by the banking industry and the amount of equity obtained from the market for the period 1996 to 2009 . Until all banks are uniformly supported by original equity, the return on equity may not be a viable tool for sector-wise analysis. Similarly, we also studied the ratio of loans to deposits but, a high statutory liquidity and cash reserve ratios in the past undermine the relevance of this ratio.

Table 2: Equity Obtained By Banks In India

\begin{tabular}{|c|c|r|}
\hline Year (ending March 31) & Number of issues & $\begin{array}{l}\text { Amount raised } \\
\text { (USS millions) }\end{array}$ \\
\hline 1996 & 17 & 1,790 \\
\hline 1997 & 10 & 1,601 \\
\hline 1998 & 8 & 568 \\
\hline 1999 & 15 & 1,117 \\
\hline 2000 & 15 & 927 \\
\hline 2001 & 13 & 674 \\
\hline 2002 & 14 & 1,055 \\
\hline 2003 & 13 & 725 \\
\hline 2004 & 11 & 1,234 \\
\hline 2005 & 12 & 2,586 \\
\hline 2006 & 12 & 2,797 \\
\hline 2007 & 5 & 504 \\
\hline 2008 & 6 & 7,760 \\
\hline 2009 & 0 & - \\
\hline
\end{tabular}

* Capital raised in Indian rupees converted and rounded off by the authors into US dollars at the interbank rate as of March 31 each year (Source: Securities and Exchange Board of India)

\section{DISCUSSION OF RESULTS}

Our models yielded expected signs for all the variables consistently. The key variables turned out to be statistically significant amidst development banking policies imposed by the government. This suggests that the country's central bank ensured maintenance of economic standards in its banking industry, however minimum levels such standards reached. Thus, the systemic risk was overall addressed prudently by the regulators. Our first model studied the importance of profitability for banks through return on assets (ROA) despite being under an administered banking environment. Tables 3 and 4 summarize our findings for the entire period of 1979 to 2009 and 2000 to 2009 respectively. The cost of funding has an immediate effect on the rate of return on loans and other investment securities. As industry modernizes on a continual basis, banks are likely to resort to inexpensive sources of funding. As and when the country's financial market harnesses its potential to offer short and long term products, banks will fund their own investments in loans through external borrowings. This may be a departure from the vanilla type of banking that the country has followed for two centuries. Traditionally, the Indian banking industry has relied upon domestic deposits as the only source of funding for all types of credit. The depositors with no alternative channel of investment were offered a high interest rate for their savings and term deposits. Besides, a sense of security for their deposits was prevalent as the banking industry represented the government itself. Depositors' overbearing reliance on interest income from transaction accounts left the government and the central bank with the only solution of offering interest rates that had no competitive market factors.

Cost of deposits was thus the primary factor in assessing the economic viability of the banking industry. Profitability increases whenever it is cheaper to borrow from the market than from mobilization of deposits. So, we 
modified our first model by including the cost of borrowings as an independent variable. The same performance ratio, ROA, was studied in the light of the length of the time period of loans and also the collateral security. The cost of deposit did not register a noticeable level of significance in all our models but the cost of borrowing and the cost of funding turned out to be highly significant. This is due to the absence of the term structure of interest rates in the past due to an administered environment. With the introduction of benchmark rates through short term treasury securities in 1997 and adoption of global standards, the reliance on deposits could be fading. Besides, the intermediation cost and employee salaries played a distinct role in reducing the overall profitability of the industry. We also noticed the return on loans and that on investment both adjusted to their respective costs registering significance. Similarly, our results comprehensively indicate that banks are likely to suffer from interest rate risk unless they are allowed to introduce hedging instruments for protecting themselves.

Table 3: Regression Results For The Indian Banking Industry (1979-2009) (Dependent Variable: ROA)

\begin{tabular}{|c|c|c|c|c|c|c|}
\hline Independent Variable & Model 1 & Model 1A & Model 2 & Model 2A & Model 3 & Model 3A \\
\hline Constant & $\begin{array}{c}0.403 \\
(1.898)^{*}\end{array}$ & $\begin{array}{c}0.352 \\
(1.731)^{*}\end{array}$ & $\begin{array}{c}0.194 \\
(0.948)^{*}\end{array}$ & $\begin{array}{c}0.118 \\
(0.570)\end{array}$ & $\begin{array}{c}-0.924 \\
(-0.945)\end{array}$ & $\begin{array}{c}0.130 \\
(0.230)\end{array}$ \\
\hline Cost of Deposits & $\begin{array}{c}0.996 \\
(2.549) *\end{array}$ & $\begin{array}{c}1.234 \\
(3.229)^{* *}\end{array}$ & $\begin{array}{c}0.925 \\
(2.228)^{*}\end{array}$ & $\begin{array}{c}1.056 \\
(2.605)^{*}\end{array}$ & & \\
\hline Cost of Borrowings & $\begin{array}{c}0.025 \\
(0.611) \\
\end{array}$ & $\begin{array}{c}0.005 \\
(0.110) \\
\end{array}$ & $\begin{array}{c}0.041 \\
(0.811) \\
\end{array}$ & $\begin{array}{c}0.032 \\
(0.641) \\
\end{array}$ & & \\
\hline Cost of Funding & $\begin{array}{c}-1.522 \\
(-3.494) * *\end{array}$ & $\begin{array}{c}-1.598 \\
(-3.830) * * *\end{array}$ & $\begin{array}{c}-1.503 \\
(-3.330)^{* *}\end{array}$ & $\begin{array}{c}-1.546 \\
(-3.466)^{* *}\end{array}$ & & \\
\hline Return on loans adjusted & $\begin{array}{c}0.436 \\
(5.530)^{* * *}\end{array}$ & $\begin{array}{c}0.395 \\
(5.149)^{* * *}\end{array}$ & $\begin{array}{c}0.343 \\
(4.668)^{* * *}\end{array}$ & $\begin{array}{c}0.298 \\
(3.873)^{* * *}\end{array}$ & & \\
\hline Return on investments & $\begin{array}{c}0.278 \\
(4.666) * * *\end{array}$ & $\begin{array}{c}0.240 \\
(4.101)^{* * *}\end{array}$ & $\begin{array}{c}0.232 \\
(3.919)^{* * *}\end{array}$ & $\begin{array}{c}0.198 \\
(3.231)^{* *}\end{array}$ & & \\
\hline Intermediation cost & $\begin{array}{c}-0.512 \\
(-2.694) * *\end{array}$ & $\begin{array}{c}-0.69 \\
(-3.610)^{* *}\end{array}$ & & & & \\
\hline Foreign banks Dummy & & $\begin{array}{c}0.914 \\
(2.973)^{* *} \\
\end{array}$ & & $\begin{array}{c}0.565 \\
(1.810)^{*}\end{array}$ & & $\begin{array}{c}-0.041 \\
(-0.325) \\
\end{array}$ \\
\hline Term Deposits to Total deposits & & & & & $\begin{array}{c}-0.021 \\
(-2.093)^{*}\end{array}$ & $\begin{array}{c}-0.003 \\
(-0.573)\end{array}$ \\
\hline Priority Sector Credit to total credit & & & & & $\begin{array}{c}0.004 \\
(0.661) \\
\end{array}$ & $\begin{array}{c}0.006 \\
(2.378)^{*}\end{array}$ \\
\hline Term Loans to Total Loans & & & & & $\begin{array}{c}0.009 \\
(1.631)\end{array}$ & $\begin{array}{c}0.004 \\
(1.946)^{*}\end{array}$ \\
\hline Secured Credit to Total Credit & & & & & $\begin{array}{c}0.020 \\
(2.815)^{* *}\end{array}$ & $\begin{array}{c}-0.003 \\
(-0.581) \\
\end{array}$ \\
\hline Net Interest Margin to Total Assets & & & & & $\begin{array}{c}-0.581 \\
(-5.518)^{* * *} \\
\end{array}$ & $\begin{array}{c}-0.088 \\
(-1.600) \\
\end{array}$ \\
\hline \multicolumn{7}{|l|}{ Non-interest income to total assets } \\
\hline Operating Profit to total assets & & & & & $\begin{array}{c}1.169 \\
(9.856)^{* * *} \\
\end{array}$ & $\begin{array}{c}0.517 \\
(7.363)^{* * *} \\
\end{array}$ \\
\hline Adjusted $\mathrm{R}^{2}$ & 0.42 & 0.43 & 0.37 & 0.39 & 0.68 & 0.69 \\
\hline Number of Observations & 89 & 89 & 89 & 89 & 88 & 88 \\
\hline
\end{tabular}

t-statistics appear in parentheses for each variable

* = significant at $90 \%$ confidence level

$* *=$ significant at $95 \%$ confidence level

$* * *$ = significant at $99 \%$ confidence level

We ensure that the independent variables are significant by including a dummy variable for the foreign banks as a group and our results reinforce our findings regularly. The foreign banks constituted to be the only unique sector wherein the dummy variable was also significant thereby suggesting that the competitive field was not open to foreign institutions for a long time. This sector operated strictly under market factors and ensured economic viability. Our final step was to understand how the industry operated with deposits as the major item on liability and 
the cost of deposits being the most expensive item on the income statement. We juxtaposed the factors of credit such as cash to deposit ratio for systemic health, priority sector credit for complying with development policies, secured credit to maintain safety and soundness, and term loans to total credit for the sake of steady cash flows. All variables registered a high level of significance wherein lies the systemic stability. When the market participants have placed a sizeable investment in banking stocks, the banking industry is under an obligation to cost reduction to render a better return on equity (ROE) consistently. Our scrutiny of the ROE as the variable dependent upon increasing interest income, maintaining a sustained net interest margin, offering more fee-based services, lowering intermediation costs, and reducing the wage expenses. The results summarized in Table 5 emphasize that the market participants do insist upon a satisfactory ROE. In this analysis, the domestic banks were on par with foreign banks.

Table 4: Regression Results For The Indian Banking Industry (2000-2009) (Dependent Variable: ROA)

\begin{tabular}{|c|c|c|c|c|c|c|}
\hline Independent Variable & Model 1 & Model 1A & Model 2 & Model 2A & Model 3 & Model 3A \\
\hline Constant & $\begin{array}{c}0.232 \\
(1.826)^{* *}\end{array}$ & $\begin{array}{c}0.105 \\
(0.920) \\
\end{array}$ & $\begin{array}{c}0.323 \\
(2.296)^{*}\end{array}$ & $\begin{array}{c}0.110 \\
(0.943) \\
\end{array}$ & $\begin{array}{c}-0.015 \\
(-0.043) \\
\end{array}$ & $\begin{array}{c}-0.089 \\
(-0.083) \\
\end{array}$ \\
\hline Cost of Deposits & $\begin{array}{c}-08.90 \\
(-0.399) \\
\end{array}$ & $\begin{array}{c}0.124 \\
(0.620) \\
\end{array}$ & $\begin{array}{c}-0.062 \\
(-0.248) \\
\end{array}$ & $\begin{array}{c}0.177 \\
(0.880) \\
\end{array}$ & & \\
\hline Cost of Borrowings & $\begin{array}{c}-0.061 \\
(-1.571) \\
\end{array}$ & $\begin{array}{c}-0.088 \\
(-2.554)^{*} \\
\end{array}$ & $\begin{array}{c}-0.053 \\
(-1.213) \\
\end{array}$ & $\begin{array}{c}-0.091 \\
(-2.585)^{*} \\
\end{array}$ & & \\
\hline Cost of Funding & $\begin{array}{c}0.003 \\
(0.013) \\
\end{array}$ & $\begin{array}{l}-0.107 \\
(0.483) \\
\end{array}$ & $\begin{array}{c}0.033 \\
(0.114) \\
\end{array}$ & $\begin{array}{c}-0.120 \\
(-0.530) \\
\end{array}$ & & \\
\hline Return on loans adjusted & $\begin{array}{c}0.094 \\
(1.874)^{*}\end{array}$ & $\begin{array}{c}0.124 \\
(2.819)^{* *} \\
\end{array}$ & $\begin{array}{c}0.229 \\
(6.042)^{* * *}\end{array}$ & $\begin{array}{c}0.176 \\
(5.675) * * * \\
\end{array}$ & & \\
\hline Return on investments adjusted & $\begin{array}{c}-0.109 \\
(-1.937)^{*}\end{array}$ & $\begin{array}{c}-0.035 \\
(-0.670) \\
\end{array}$ & $\begin{array}{c}0.036 \\
(0.817) \\
\end{array}$ & $\begin{array}{c}0.030 \\
(0.870) \\
\end{array}$ & & \\
\hline Intermediation cost & $\begin{array}{c}0.603 \\
(3.592)^{* *}\end{array}$ & $\begin{array}{c}-0.274 \\
(1.641)^{* *}\end{array}$ & & & & \\
\hline Foreign banks Dummy & & $\begin{array}{c}0.581 \\
(3.958)^{* * *}\end{array}$ & & $\begin{array}{c}0.701 \\
(5.3988) * * * \\
\end{array}$ & & $\begin{array}{c}-0.486 \\
(-1.833)^{*} \\
\end{array}$ \\
\hline Term Deposits to Total deposits & & & & & $\begin{array}{c}-0.003 \\
(-0.601)^{*}\end{array}$ & $\begin{array}{c}-0.018 \\
(-1.729)^{*}\end{array}$ \\
\hline Priority Sector Credit to total credit & & & & & $\begin{array}{c}0.006 \\
(0.661) \\
\end{array}$ & $\begin{array}{c}0.007 \\
(1.027) \\
\end{array}$ \\
\hline Term Loans to Total Loans & & & & & $\begin{array}{c}0.005 \\
(2.176)^{*}\end{array}$ & $\begin{array}{c}0.006 \\
(1.046) \\
\end{array}$ \\
\hline Secured Credit to Total Credit & & & & & $\begin{array}{c}-0.002 \\
(-0.558) * *\end{array}$ & $\begin{array}{c}0.009 \\
(0.983) \\
\end{array}$ \\
\hline Net Interest Margin to Total Assets & & & & & $\begin{array}{c}-0.088 \\
(-1.603) \\
\end{array}$ & $\begin{array}{c}-0.597 \\
(-5.732)^{* * *}\end{array}$ \\
\hline \multicolumn{7}{|l|}{ Non-interest income to total assets } \\
\hline Operating Profit to total assets & & & & & $\begin{array}{c}0.521 \\
(7.609)^{* * * *}\end{array}$ & $\begin{array}{c}1.216 \\
(10.158)^{* * *} \\
\end{array}$ \\
\hline Adjusted $\mathrm{R}^{2}$ & 0.65 & 0.76 & 0.56 & 0.74 & 0.92 & 0.92 \\
\hline Number of Observations & 49 & 49 & 49 & 49 & 48 & 48 \\
\hline
\end{tabular}

t-statistics appear in parentheses for each variable

* = significant at $90 \%$ confidence level

$* *=$ significant at $95 \%$ confidence level

$* * *=$ significant at $99 \%$ confidence level

\section{CONCLUSION AND FUTURE DIRECTION}

With the advent of a significant presence of private banks and foreign banks, the Indian banking industry has the potential to become modern and sophisticated. The public sector banks need original equity from the public. If a fresh infusion of capital were to take place, the market will look for a privatized industry. In such an environment, bank managements are certain to be efficient, but the responsibility of protecting the investors from 
the risk of moral hazard solely rests with the regulators. The foreign direct investment (FDI) policy of India permitted a complete ownership of banks by foreign investors since 2000, but there has been only one merger with ING's acquisition of the Vysya Bank Limited. Liberalization efforts have been steady but considerably slowed down due to resistance from pressure groups such as trade unions. The reason that the financial services industry overall has suffered from the nonperforming assets (NPAs) and also a foreign investor may not fully comprehend what to expect as a measure of performance. In its assessment of Basel core principles, as applied to the commercial banking industry in India, the Reserve Bank of India finds banks in India to be compliant with regards to capital adequacy, large exposure limits, and country \& transfer risk. They are also largely compliant in the areas of credit risk, problem assets, provisions \& reserves, operational risk, internal control \& audit, and abuse of financial services. The concern stems from banks found to be materially non-compliant in addressing risk management process, exposure to related parties, market risk, and liquidity risk. Most importantly, commercial banks are non-compliant in measuring and controlling interest rate risk in banking books. ${ }^{2}$

Table 5: Regression Results For The Indian Banking Industry (1979-2009)

\begin{tabular}{|c|c|c|c|c|}
\hline Dependent Variable: ROE & Model 4 & Model 4A & Model 5 & Model 5A \\
\hline & $1979-2009$ & $1979-2009$ & $2000-2009$ & $2000-2009$ \\
\hline Constant & $\begin{array}{c}21.966 \\
(2.437)^{*}\end{array}$ & $\begin{array}{c}23.481 \\
(2.552)^{*}\end{array}$ & $\begin{array}{c}2.370 \\
(1.186)\end{array}$ & $\begin{array}{c}3.056 \\
(1.421)\end{array}$ \\
\hline Interest income to total assets & $\begin{array}{c}-3.474 \\
(-1.873)^{*}\end{array}$ & $\begin{array}{c}-4.252 \\
(-2.054)^{*}\end{array}$ & $\begin{array}{c}1.869 \\
(5.497)^{* * *}\end{array}$ & $\begin{array}{c}1.611 \\
(3.578)^{* *}\end{array}$ \\
\hline Net interest margin to total assets & $\begin{array}{c}2.559 \\
(0.552)\end{array}$ & $\begin{array}{c}3.103 \\
(0.663)\end{array}$ & $\begin{array}{c}7.126 \\
(4.944)^{* * *}\end{array}$ & $\begin{array}{c}7.275 \\
(5.000)^{* * *}\end{array}$ \\
\hline Non-interest income to total assets & $\begin{array}{c}2.677 \\
(0.530)\end{array}$ & $\begin{array}{c}4.181 \\
(0.780)\end{array}$ & $\begin{array}{c}2.833 \\
(2.217)^{*}\end{array}$ & $\begin{array}{c}2.959 \\
(2.295)^{*}\end{array}$ \\
\hline Intermediation cost to total assets & $\begin{array}{c}10.350 \\
(1.681)^{*}\end{array}$ & $\begin{array}{c}12.398 \\
(1.873)^{*}\end{array}$ & $\begin{array}{c}-11.853 \\
(-5.841)^{* * *}\end{array}$ & $\begin{array}{c}-11.223 \\
(-5.202) * * *\end{array}$ \\
\hline Wages to total income & $\begin{array}{c}-1.184 \\
(-2.960) * *\end{array}$ & $\begin{array}{c}-1.312 \\
(-3.067) * *\end{array}$ & $\begin{array}{c}-0.041 \\
(-0.319)\end{array}$ & $\begin{array}{c}-0.076 \\
(-0.564)\end{array}$ \\
\hline Foreign banks dummy & & $\begin{array}{c}-6.987 \\
(-0.850) \\
\end{array}$ & & $\begin{array}{l}-1.378 \\
(0.384)\end{array}$ \\
\hline Adjusted $\mathrm{R}^{2}$ & 0.23 & 0.23 & 0.74 & 0.73 \\
\hline Number of observations & 117 & 117 & 49 & 49 \\
\hline
\end{tabular}

t-statistics appear in parentheses for each variable

* = significant at $90 \%$ confidence level

$* * \quad=$ significant at $95 \%$ confidence level

$* * *$ = significant at $99 \%$ confidence level

Our study also reinforces the same point of view, but we understand that the regulations may only pave the way for market evolution and infrastructure enhancement. The introduction of real time gross settlement (RTGS) recently is a major step to suggest that India's banking industry is prepared to be modernized, which is consistent with industrialized economies. The risk management systems are mostly proprietary and so require each individual bank's commitment to enforce stringent internal control mechanism while bestowing a sophisticated degree of autonomy on the management. Adequate risk management systems determine the health of each institution cumulatively contributing to the robust systemic health. In order to fulfill this area, an expansion of this study must be undertaken from the perspective of each individual major bank under each sector in order to conclude which banks are likely to be fully compliant with regards to risk management systems. Implementation of core banking system is just the beginning of India's banking industry which was necessitated by the advent of rapid technology amidst its consumers. The same customers are engaged in the changing landscape of the whole industry.

\footnotetext{
2 The Reserve Bank of India, Report of the Committee on Financial Sector Assessment, Volume I, Page 25, Table III.1:
} Assessment of Basel Core Principles - Commercial Banks 


\section{AUTHOR INFORMATION}

Dr. Sivakumar Venkataramany serves as Professor of International Business in the Dauch College of Business \& Economics at Ashland University, Ashland, Ohio where he teaches global management and global finance. . He received his MBA, MS and Ph.D. from the University of Miami, Coral Gables, Florida. His research interests are risk management in global banks, emerging financial markets and FDI in developing economies. He has several teaching commitments abroad and serves as an examiner for doctoral theses. E-mail: Svenkata@ashland.edu. Corresponding author.

Dr. Balbir B. Bhasin serves as Ross Pendergraft Endowed Professor of International Business in the University of Arkansas, Fort Smith, Arkansas. He holds a Master of International Management (M.I.M.) degree from Thunderbird School of Global Management, Glendale, Arizona and a Ph.D. in International Business from the University of South Australia, Adelaide, Australia. He was the president of a private investment bank in New York, and CEO of an international business information company in the Far East. His research interests are in cross-cultural studies and FDI in Asian markets. He advises companies on opportunities in Emerging Asia. E-mail: balbir.bhasin@uafs.edu.

\section{REFERENCES}

1. Arora, Parvinder; Garg, Ajay; and Ranjan, Bhavna, "The ALM Practices in Commercial Banks in India", ICFAI Journal of Applied Finance, Oct2007, Vol. 13 Issue 10, pp. 79-96

2. Bandyopadhyay, Arindam, "Credit Risk Models for Managing Bank's Agricultural Loan Portfolio", ICFAI Journal of Financial Risk Management, Dec2008, Vol. 5 Issue 4, pp. 86-102

3. Bodla, B. S.; and Verma, Richa, "Credit Risk Management Framework at Banks in India", ICFAI Journal of Bank Management, Feb2009, Vol. 8 Issue 1, pp. 47-72

4. Bodla, B. S.; Verma, Richa, "Operational Risk Management Framework at Banks in India”, ICFAI Journal of Financial Risk Management, Dec2008, Vol. 5 Issue 4, pp. 63-85

5. Ghosal, Pallabi, "The Road Ahead for NBFCs Becoming Banks After Basel II Norms: The Indian Scenario", Banking Law Journal, Nov/Dec2008, Vol. 125 Issue 10, pp. 938-953

6. Janakiraman, Usha, "Operational Risk Management in Indian Banks in the Context of Basel II: A Survey of the State of Preparedness and Challenges in Developing the Framework", Global Journal of Finance \& Banking Issues, July2008, Vol. 2 Issue 2, pp. 26-43

7. Jayadev, M.; Sensarma, Rudra., "Mergers in Indian Banking: An Analysis", South Asian Journal of Management, Oct-Dec2007, Vol. 14 Issue 4, pp. 20-49

8. Khanna, Vijay Kumar, "Risk-Based Internal Audit in Indian Banks: A Modified and Improved Approach for Conduct of Branch Audit”, ICFAI Journal of Audit Practice, Oct2008, Vol. 5 Issue 4, pp. 35-56.

9. Nachane, D. M.; Ghosh, Saibal, "Credit Rating and Bank Behaviour in India: Possible Implications of the New Basel Accord”, Singapore Economic Review, Apr2004, Vol. 49 Issue 1, pp. 37-54

10. Saha, Asish; Subramanian, V.; Basu, Sanjay; and Mishra, Alok Kumar, "Networth Exposure to Interest Rate Risk: An Empirical Analysis of Indian Commercial Banks", European Journal of Operational Research, Mar2009, Vol. 193 Issue 2, pp. 581-590

11. Sensarma, Rudra; Jayadev, M., “Are Bank Stocks Sensitive to Risk Management?”, Journal of Risk Finance, 2009, Vol. 10 Issue 1, pp. 7-22

12. Sinha, Ram Pratap "Business Efficiency of Public Sector Commercial Banks: A Data Envelopment", ICFAI Journal of Applied Economics, Jan2008, Vol. 7 Issue 1, pp. 7-27

13. Sinha, Ram Pratap, "Performance Evaluation of Indian Commercial Banks in the Prompt Corrective Action Framework: An Assurance Region Approach", ICFAI Journal of Financial Risk Management, Mar 2008, Vol. 5 Issue 1, pp. 29-40

14. Swati Singhal; Madhu Vij, "Convergence in Financial Services Industry: Trends and Issues in Regulation and Supervision", Journal of Management Research, Apr2006, Vol. 6 Issue 1, pp. 48-56 